\title{
AN INVESTIGATION ON THE SCOPE OF THE CONCEPT OF BIODIVERSITY IN TURKEY AT HIGH SCHOOL GEOGRAPHY CURRICULUM ${ }^{\mathrm{i}}$
}

\author{
Ziya Ince ${ }^{\mathrm{ii} 1}$, \\ Vedat Şahin ${ }^{2}$ \\ ${ }^{1}$ Assist Prof. Dr., \\ Namık Kemal University, \\ Department of Geography, \\ Tekirdag, Turkey \\ ${ }^{2}$ Assoc. Prof. Dr., \\ Namık Kemal University, \\ Department of Geography, \\ Tekirdag, Turkey
}

\begin{abstract}
:
One of the definitions of biodiversity, which has many definitions, is the differences between living things or the diversity of life forms in the world. According to another definition, biodiversity is a group of wholes formed by genes, species, ecosystems and ecological events in a region. The importance of biodiversity is gradually increasing nowadays where some living species existing on earth are gradually disappearing. In this context, many disciplines have started to work on this subject. Studies in the fields of biology and science are especially important. On the other hand, although some studies have been done on the subject in the field of geography, studies on the place of biodiversity in geography education are limited. Biodiversity; Turkey has not received the place it deserves due to be reduced to just one unit in the Geography Curriculum. Biodiversity, due to the reduction to only one unit in the Geography Curriculum in Turkey, it has not received its deserved place. Because, when the secondary education geography curriculum is examined, it is seen that only in the first unit of $11^{\text {th }}$ grade includes biodiversity. Likewise, there is only one learning outcome directly related to the subject in the Geography Education Program. Document analysis technique, which is one of the qualitative research methods, was used in our research. In the research, the place of biodiversity subject in secondary education geography curriculum was examined. Within this framework, journals, articles, books of academic value and reports containing statistical data that are published regarding to the topic were reviewed. In this context,
\end{abstract}

\footnotetext{
i This article was presented as a summary paper at the International Battalgazi Scientific Studies Congress, 18-20, 2020 / Malatya. “Türkiye' de Lise Coğrafya Öğretim Programında Biyoçeşitlilik Kavramının Kapsamı Üzerine Bir İnceleme.

ii Correspondence email: zince@nku.edu.tr
} 
many resources published in domestic and foreign languages on the internet has been scanned. In conclusion, in order for the biodiversity of what our country has, to be understood in terms of the whole society, this existence must be well known and assimilated. It gains importance to increase the efforts to transfer the biological diversity that exists in our day to future generations. Geography education is one of the most important factors in order to increase the level of awareness in this regard. In this context, it is important to allocate more space for this subject in different units in the secondary education geography curriculum.

Keywords: biodiversity, geography education, geography education program, curriculum

\section{Özet:}

Birçok tanımı olan biyoçeşitliliğin bir tanımı, canlılar arasındaki farklılıklar veya dünyadaki yaşam formlarının çeşitliliğidir. Bir başka tanıma göre ise biyoçeşitlilik; bir bölgedeki genlerin, türleri, ekosistemlerin ve ekolojik olayların oluşturduğu bütünler topluluğudur. Yeryüzünde var olan bazı canlı türünün yavaş yavaş yok olduğu günümüzde biyoçeşitliliğin önemi giderek artmaktadır. Bu bağlamda birçok disiplin bu konuda çalışmalar yapmaya başlamıştır. Bunlardan özellikle biyoloji ve fen bilimleri alanlarındaki çalışmalar önemlidir. Diğer yandan coğrafya alanında konu üzerine bazı çalışmalar yapılmış olsa da coğrafya eğitimi içinde biyoçeşitliliğin yeri konusunda çalışmalar sınırlıdır. Biyoçeşitlilik; Türkiye'de Coğrafya Öğretim Programında sadece bir üniteye indirgenmesinden dolayı hak ettiği yeri almamıştır. Çünkü ortaöğretim coğrafya müfredatı incelendiğinde sadece 11.sınıfın 1.ünitesinde biyoçeşitliliğin yer aldı̆̆ı görülmektedir. Aynı şekilde Coğrafya Öğretim Programında konuyla doğrudan ilgili yalnız bir kazanım yer almaktadır. Araştırmamızda nitel araştırma yöntemlerinden doküman analizi tekniği kullanılmıştır. Araştırmada biyoçeşitlilik konusunun ortaöğretim coğrafya öğretim programlarındaki yeri incelenmiştir. Bu çerçevede konu üzerine yayınlanmış akademik değeri olan dergi, makale, kitap ve istatistik verileri içeren raporlar gözden geçirilmiştir. Bu kapsamda internet ortamında yer alan yerli ve yabancı dilde yayınlanmış birçok kaynak taranmıştır. Sonuç olarak ülkemizin sahip olduğu biyoçeşitliliğin bütün toplum bakımından anlaşılması için öncelikle bu varlığının iyi bilinmesi ve özümsenmesi gerekir. Bu gerçekleştirildikten sonra, gelecek nesillere günümüzde var olan biyolojik çeşitliliğin aktarılması için çalışmaların attırılması önem kazanır. Bu konuda bilinç düzeyinin arttırılması için en önemli araçlardan biri coğrafya eğitimidir. Bu bağlamda ortaöğretim coğrafya müfredatında bu konuya farklı üniteler içinde yer alacak şekilde daha fazla yer ayrılması önemlidir.

Anahtar kelimeler: biyoçeşitlilik, coğrafya eğitimi, coğrafya öğretim programı, müfredat 


\section{Introduction}

There are many definitions of biodiversity, which is described as the diversity of life forms on Earth. Biological diversity or biodiversity is generally defined as all the diversity of life on earth. Species, genetic and ecosystem diversity in a area; it sometimes includes related abiotic components such as landscape features, drainage systems and climate (Swingland, 2001). For this reason, it is a concept that expresses the diversity of all living organisms contained in terrestrial, marine and other aquatic ecosystems (Avc1, 2016, p.166). Biodiversity includes all living organisms that are found on Earth. It plays a key role in the functioning of ecosystems and in the provision of ecosystem services necessary for human life and well-being (EEA, 2015).

Studies on biological diversity have accelerated due to the concerns about the extinction of living species in natural environments as a result of human activities after the 1980s. The Rio summit was planned as a result of the damage to biological diversity resources, which are important for economic and social development, due to humaninduced activities and the extinction of some species are reaching to alarming rates (MFA, 2020). 1992 UN Rio Summit is the most important meeting that aimed at the conservation of biological diversity. One of the clearest results of this meeting is the creation of the Biological Diversity Convention. The foundations of the Convention on Biological Diversity were laid by the United Nations Environment Program (UNEP) in 1987, and the Convention were adopted at the United Nations Conference on Environment and Development that were held in Rio de Janeiro on 5 June 1992 with the participation of 150 countries (RG., 1996). This agreement brings certain obligations to the parties. The most important of these obligations are: prioritizing the species or regions in need of protection most urgently, determining protected areas, making legal and administrative arrangements related to the contract and educating the public about biodiversity.

The Convention on Biological Diversity is open to the development of comprehensive national programs and policies for parties to fulfill their obligations. For this reason, with the participation of all relevant institutions and organizations by the Ministry of Environment and Forests in Turkey, Turkey's National Biological Diversity Strategy and Action Plan (NBSAP) has been prepared (TUBÇSEP, 2007). In this convention, "biodiversity" is the differentiation between land, marine and aquatic ecosystems and all living organisms, including the ecological complexes of which these ecosystems are a part, and are expressed in a way that includes the status of species within themselves, species and ecosystem diversity (RG., 1996).

Many activities are taking place for biodiversity around the world. One of the most important agreements among these are 1971 dated Ramsar Treaty, where Turkey became a party to it in 1994 (Çetiner, 2010). Despite the Rio Convention on Biodiversity of 1992 and the Cartagena Biosafety Protocol, which entered into force in 2003, there weren't much improvement in the protection of biodiversity in Turkey and international platforms (Çetiner, 2010). This situation once again reveals the importance of education. 
The conservation of biological diversity takes place together with the protection of nature and increasing environmental quality by adhering to the principles of sustainability (Doğan, Türk, Doğan, \& Kesik, 2018).

Activities in this field are spreading around the world. However, one of the major problems in the protection of biodiversity is that enough value is not given to the natural resources. The costs of damaging natural resources are not taken seriously, and the decrease in biodiversity in a place is not emphasized much (Avc1, 2016, s. 184). However, the protection of biodiversity is an important issue in itself. On the other hand, countries located in tropical areas is among the richest countries in terms of biodiversity, geographical location of Turkey, as a result of the diversity of climatic conditions and landforms, is among the most important countries of the world. (Avc1, 2016, s. 167). In this context, genetic diversity that exists in Demirayak's (2002) classification, in terms of subjects involving species diversity and ecosystem diversity: Turkey is in quite advantageous position. Because the fact that Turkey is a country with different climatic and topographic characteristics and is in the transition regions of Iran-Turan, EuropeSiberia and Mediterranean biogeographies, has enabled biodiversity for it (Akgündüz, Karauz, Özüdoğru, Çekiç, \& Kalaycı, 2012). However, understanding the importance of this and increasing the level of consciousness is only possible if the teaching of these subjects takes a place in the education system.

\section{Literature review}

When we look at the literature, it is seen that the studies in the field of biodiversity are mostly limited to biology sciences. For example, what Dilbirliği (2007) did in his study on biodiversity, plant genetic resources and domestic animal genetic resources, he conducted surveys regarding the things that should be done to protect biodiversity were conducted and some results were obtained. Bulut (2019) prepared an interdisciplinary study to learn the views of teachers on biodiversity, to see that whether teachers know the biodiversity of the regions where they work at and to determine how teachers are handling this subject in their lessons. According to this study, it was understood that the teachers had some knowledge about the diversity of species, ecosystem and ecosystem functions related to the scope of biodiversity. It has been determined that the concept of biodiversity is generally expressed by teachers as species diversity reduces the scope of this subject and creates an obstacle to attributing the necessary importance to the subject. The study prepared by Deniz (2019) about the effects of unplanned tourism activities on wildlife, biodiversity, ecosystem, habitat and population, and measures to be taken is important, because unplanned tourism activities that are carried out without properly evaluating their effects on biodiversity can pose a threat to biological diversity and ecosystems.

According to the research carried out by Derman et al. (2013) on the importance of biodiversity in terms of sustainable development and the examination about the place of biodiversity in the education programs of our country, it has been concluded that there 
are not enough studies on biodiversity and the knowledge level of students on biodiversity is low. On the other hand, Gürbüz and et al. (2013) carried out a large-scale study for the biodiversity literacy scale to be developed.

In the study conducted by Stahl et.al (2020), it has been determined that especially the textbooks are not fair and exhibit prejudices in terms of protecting species diversity in the world and not accurately reflecting the biological diversity of the world. It has also been concluded that the scope of modern conservation biology textbooks is biased and this may have important consequences for the training of the next generation of scientists and practitioners.

In order to provide a meaningful learning about biological diversity, student guide materials were designed by Keleş and Özenoğlu (2017) in accordance with the stated learning outcomes in the Science curriculum. According to these materials, a plan was designed to provide students a meaningful learning about biological diversity with the 5 E model.

In the study prepared by Kurumlu et al. (2010), the competencies, knowledge levels and self-efficacy perceptions of biology teachers on biodiversity and conservation strategies were investigated. As a result of the research, it is deemed necessary for teachers to participate in activities that will increase their knowledge about biodiversity and to make up for their deficiencies in terms of both their professional progress and the education of students.

Crisci and Katinas (2011) stated in their study that school curricula should include active problem-solving activities and also biodiversity and humankind addiction issues should also be included. For example, it is stated in the same study (Crisci \& Katinas, 2011) that restructuring and modernizing the high school biology schedule will increase students' interest in biological diversity.

Okur, Yalçın, and Şahin (2011) conducted research on classroom teachers to determine the methods commonly used in teaching the concept of biological diversity.

\section{Purpose and Importance of the Research}

The aim of our research is to examine the place of biodiversity subject in geography curriculum in terms of learning outcomes and current developments. As can be seen in the researches in the literature, although it is an issue of worldwide importance, the fact that there is no important study on this subject in the field of geography and the fact that it is only mentioned and passed on this subject in the textbooks reveals the importance of research on this subject. Evaluating the place of biodiversity in secondary education curricula in this study will fill an important gap.

\section{Material and Methods}

Document analysis technique, which is one of the qualitative research methods, was used in our research. For the analysis of the data, descriptive analysis method was preferred. 
According to Yıldırım and Şimşek (2013), document review includes the analysis of written materials containing information about the phenomenon or facts to be investigated. A literature review and document analysis related to the learning outcomes regarding the concept of biodiversity in the geography curriculum were carried out. According to the data obtained, biodiversity was tried to be explained in terms of geography lesson.

\section{Results and Discussion}

A comparative or descriptive analysis of the study based on results, on previously studies, etc. The results should be presented in a logical sequence, given the most important findings first and addressing the stated objectives. The number of tables and figures should be limited to those absolutely needed to confirm or contest the premise of the study. The authors should deal only with new or important aspects of the results obtained. Material from the Results section should not be repeated, nor new material introduced. The relevance of the findings in the context of existing literature or contemporary practice should be addressed.

\section{Findings}

The concept of biodiversity is today a subject that is being studied and researched by different branches of science and different institutions. Research on biodiversity is carried out in biology, science, tourism, environmental engineering, forest engineering, veterinary medicine, nature conservation and many other fields. In the researches mentioned in the literature review is shown that in Turkey, there are publications more on this issue in the field of biology.

In the field of geography, biodiversity is included in different courses at higher education level. In the subject context, they are discussed in detail under the headings like biogeography, biodiversity, environment, ecology, ecosystem change, global climate change, Turkey's biodiversity, environmental problems, systematics of biological diversity, endemism and biodiversity, ecological biogeography.

It is seen in Turkey that biodiversity subject at secondary education level take limited place. When the Secondary School Geography Curriculum (MEB, 2018) is examined (Table 1), it is seen that there is only one learning outcome in one subject regarding the concept of biodiversity. 


\begin{tabular}{|c|c|c|c|}
\hline \multicolumn{4}{|c|}{ Table 1: Biodiversity in the Geography curriculum } \\
\hline Course title & Chapter & $\begin{array}{c}\text { Unit } \\
\text { Description }\end{array}$ & $\begin{array}{c}\text { Related Learning } \\
\text { Outcomes }\end{array}$ \\
\hline $\begin{array}{l}\text { 11" Grade Geography } \\
\text { Curriculum }\end{array}$ & 11.1. Natural Systems & $\begin{array}{l}\text { In this unit, the factors } \\
\text { that are effective in the } \\
\text { formation and } \\
\text { reduction of } \\
\text { biodiversity, the } \\
\text { elements that make up } \\
\text { the ecosystem, material } \\
\text { cycles and energy flow } \\
\text { and water ecosystems } \\
\text { will be covered, } \\
\text { respectively. }\end{array}$ & $\begin{array}{l}\text { 11.1.1. Explains the } \\
\text { factors affecting the } \\
\text { formation and } \\
\text { reduction of } \\
\text { biodiversity. } \\
\text { It is ensured that } \\
\text { students collect } \\
\text { information about the } \\
\text { studies carried out for } \\
\text { the protection of } \\
\text { biodiversity, and } \\
\text { prepare public service } \\
\text { announcement in order } \\
\text { to raise awareness of } \\
\text { the public about the } \\
\text { protection of } \\
\text { biodiversity } \\
\text { individually or as a } \\
\text { group. }\end{array}$ \\
\hline
\end{tabular}

Source: (MEB, 2018).

In the geography curriculum, biodiversity takes place as the first learning outcome under the Natural Systems unit, which is the first unit at the $11^{\text {th }}$ grade. In this learning outcome (11.1.1. Explains the factors affecting the formation and reduction of biodiversity), the factors that play a role in the formation and reduction of biodiversity of students were discussed. In this regard, the definition of biodiversity, its distribution, and the richness of biodiversity in our country are not mentioned. In these respects, it is seen as insufficient to explain the subject.

Despite the high level of biological richness in our country, it is a complete disappointment to not include a learning outcome in the geography teaching program. In our country, there are more than 9,000 plant species, more than 60 thousand insect species, more than 400 bird species, 276 marine and 192 freshwater fish species, more than 120 mammals, more than 90 reptile species are available. While there are 12500 open and closed seed plant species in the whole European continent, it is known that there are close to this number (about 11707) only in Anatolia (nuhungemisi.gov.tr, 2019). This situation shows that our country is very rich in biodiversity.

However, despite all this richness, it is not appropriate to give only one learning outcome in the geography curriculum for the promotion of biodiversity, whereas it is seen that the biodiversity issue at middle school level ( $5^{\text {th }}$ grade) is represented with two learning outcomes.

The subject of biodiversity is included in the $6^{\text {th }}$ unit (Table 2 ) in the Science course curriculum (MEB, 2018b) at the $5^{\text {th }}$ grade level of secondary school. When the learning 
outcomes are examined, it is seen that it has a more inclusive structure than the geography curriculum.

Table 2: Biodiversity at the secondary school science course curriculum

\begin{tabular}{|c|c|c|c|}
\hline Course title & Chapter & $\begin{array}{c}\text { Unit } \\
\text { Description }\end{array}$ & $\begin{array}{l}\text { Related Learning } \\
\text { Outcomes }\end{array}$ \\
\hline $\begin{array}{l}5^{\text {th }} \text { Grade Science } \\
\text { Course Curriculum }\end{array}$ & $\begin{array}{l}\text { F.5.6. Human and } \\
\text { Environment / } \\
\text { Creatures and Life }\end{array}$ & $\begin{array}{l}\text { In this unit, it is aimed } \\
\text { that students can } \\
\text { question the causes and } \\
\text { consequences of } \\
\text { environmental } \\
\text { problems, biodiversity } \\
\text { and what should be } \\
\text { done to protect the } \\
\text { endangered and living } \\
\text { species in danger of } \\
\text { extinctions, awareness } \\
\text { of environmental } \\
\text { problems caused by } \\
\text { human activities, and } \\
\text { gain knowledge and } \\
\text { skills to solve these } \\
\text { problems. }\end{array}$ & $\begin{array}{l}\text { F.5.6.1. Biodiversity } \\
\text { Lesson Duration: } 6 \\
\text { lesson hours } \\
\text { Subject / Concepts: } \\
\text { Biodiversity, natural } \\
\text { life, endangered } \\
\text { creatures, habitat, } \\
\text { ecosystem } \\
\text { F.5.6.1.1. Questions the } \\
\text { importance of } \\
\text { biodiversity for natural } \\
\text { life. } \\
\text { It gives examples of } \\
\text { plants and animals that } \\
\text { are endangered or in } \\
\text { danger of extinction in } \\
\text { our country and in the } \\
\text { world. } \\
\text { F.5.6.1.2. Discussing the } \\
\text { factors threatening } \\
\text { biodiversity based on } \\
\text { research data. }\end{array}$ \\
\hline
\end{tabular}

Source: (MEB, 2018b).

It is seen that the subject of biodiversity in the $6^{\text {th }}$ unit of the $5^{\text {th }}$ grade science course curriculum of the middle school consists of two learning outcomes. Therefore, it has a wider structure in terms of both scope and area.

When the annual lesson plan is considered, it is seen that the learning outcomes on biodiversity in the geography curriculum are planned to be covered with a 2-hour course.

However, this subject has took place in the minds of students only within the framework of the definition of the concept of biodiversity and what it stands for.

When $11^{\text {th }}$ grade textbooks are examined, it is seen that the subject of biodiversity is covered with 4-5 pages under the title "biodiversity and ecological cycles" and especially the distribution of species diversity in the world is explained.

In this context, it is important to establish the protection of biodiversity in the world with education, which aims to produce expected behaviors in humans. Therefore, the wider the subject in education programs, the more biodiversity textbooks will include. As a result of this, it will be adopted and understood by the students. 
Apart from education, one of the positive developments protecting biodiversity in the world is organic agriculture. In organic farming, species that survive without human intervention are protected. According to the study conducted by the FAO (2019) observed until today, Turkey has reached the highest organic farming level ever seen due to developing organic farming activities. In this context, the issues involving the importance of biodiversity and organic agriculture should be taught to students. For this, "reading passages" can be included in the textbooks.

\section{Result and Discussion}

The conservation and sustainable use of biodiversity is not only an environmental issue, but also a fundamental requirement for our nutrition, production processes, services and overall good quality of life (Food \& Biodiversity, 2020). In this respect, studies on biological diversity are increasing without slowing down. When we look at the United Nations Sustainable Development Goals, while the entire Article 16 ultimately affect biodiversity, especially Articles 14 and 15 are all about the importance of biodiversity (UNDP.org, 2020).

When the reasons for this subject to be considered so important are examined, it is seen that the future of humanity is being planned and trying to be guaranteed. When we look at what is the reason for the importance of biological diversity lately, we can't ignore that a balance exists, because biological diversity is essential for the continuation of human life. Some of the species in biodiversity provide opportunities for people in the field of industry, such as agriculture, medicine and food. This situation also improves the economies of the countries.

To ensure that ecosystems are beneficial and be able to reach their full potential, it is vital that biodiversity considerations are taken into account by the Nature-Based System (NBS) design and not sacrificed in light of other priorities (Naumann \& Davis, 2020).

In today's world, where the concept of biodiversity is gaining importance, studies in this field, especially in the field of biology, stands out. However, it is seen that this subject did not reach its deserved place in the geography curriculums that we examined in our research, because it is thought that a biodiversity concept, which is expressed with only one acquisition in a whole curriculum, cannot be taught enough. However, it is seen that biodiversity subject, albeit in different names, are given wide coverage in higher education geography departments and even in graduate programs this subject is included as a separate course.

When we look at Turkey Qualifications Database, in the Geography undergraduate diploma qualification information detail section; expressing that modern geography studies play a key role in understanding and solving current problems such as global warming, desertification, biodiversity, nature protection, pollution, urbanization, underdevelopment and globalization (TYVT, 2020) reflects the importance of the subject in terms of geography education. 


\section{Conclusion}

Results of the research is the abundance of studies in the literature on biodiversity. However, it is observed that these studies in the field of biodiversity and education are mostly limited to biology and science. For this reason, it is necessary to increase the work done in this field, to concentrate on interdisciplinary studies and to increase the weight of this issue in other disciplines and especially in geography.

It would be appropriate to place the biodiversity issues, which are also among the United Nations Sustainable Development Goals, in the secondary education geography curriculum starting from the 9th grade in a spiral manner as at least two learning outcomes on the basis of all classes and expressing these studies as project-based and skill learning outcome at the same time.

Some suggestions can be made based on the results obtained at the end of this research. One of these suggestions is to include the subject of biodiversity in the Secondary Education Geography Curriculum with more learning outcomes on the basis of all classes. In addition, it is important to plan more biodiversity-related activities in schools, to ensure that these activities are in a style that will transform the subject of biodiversity into permanent learning, and to give a wider place to biodiversity in geography textbooks.

It is recommended to plan seminars, develop interdisciplinary projects on biodiversity and add reading passages to the textbooks in order to raise awareness of parents as well as students on biodiversity through education.

\section{Conflict of Interest Statement}

The authors declare no conflicts of interests.

\section{About the Authors}

Ziya İnce is an Asst. Prof. at Namık Kemal University, Tekirdağ, Turkey. He is currently working at the Geography Department at the same university. He holds a PhD degree in Geography Education.

Vedat Şahin is an Assoc. Prof. at Namık Kemal University, Tekirdağ, Turkey. He is currently working at the Geography Department at the same university.

\section{References}

Akgündüz, E., Karauz, E. S., Özüdoğru, E., Çekiç, A. O., \& Kalaycl, K. (2012). Türkiye biyolojik çeşitliliğinin coğrafi bilgi sistemleri yardımıyla izlenmesi: nuh'un gemisi biyolojik çeşitlilik veritabanı. Biyolojik Çeşitlilik Sempozyumu (22-23 Mayıs-2012) Bildiri Kitabı (s. 8-9). Ankara: Tarım Orman ve Su İşleri Bakanlığı, Biyolojik Çeşitlilik Daire Başkanlığı. 
Avcı, M. (2016). Ekosistem Coğrafyası. İstanbul: İstanbul Üniversitesi, Açık ve Uzaktan Eğitim Fakültesi, Coğrafya Lisans Programı, ISBN 978-605-07-0674-1.

Bulut, M. (2019). Fen bilimleri, biyoloji, coğrafya ve sosyal bilgiler öğretmenlerinin biyoçeşitlilik konusundaki görüşleri ve çalıştıkları bölgedeki biyoçeşitliliği derslerinde işleme düzeyleri. Sakarya: Sakarya Üniversitesi, Eğitim Bilimleri Enstitüsü, Matematik ve Fen Bilimleri Eğitimi Anabilim Dalı, Fen Bilgisi Eğitimi Bilim Dalı, Basılmamış Yüksek Lisans Tezi.

Çetiner, S. (2010). Biyoçeşitlilik nedir? Ne değildir? TarlaSera Aylık Tarım ve Kültür Dergisi, Kasım sayısı, sayfa:14-16.

Demirayak, F. (2002). Biyolojik çeşitlilik-doğa koruma ve sürdürülebilir kalkınma. Ankara: TUBITAK, Aralik 2002 Vizyon-2023, Biyolojik Çeşitliliğin Korunması ve Sürdürülebilir Kalkınma Paneli için hazırlanan Rapor.

Deniz, T. (2019). Turizm ve biyoçeşitlilik. Safran Kültür ve Turizm Araştırmaları Dergisi, 2(3), 323-339.

Derman, M., Çakmak, M., Yaşar, M. D., Kızılaslan, A., \& Gürbüz, H. (2013). Biyoçeşitlik konusunda yapılan çalışmalar ve öğretim programlarında biyoçeşitliliğin değerlendirilmesi. Eğitim ve Öğretim Araştırmaları Dergisi (JRET), Cilt:2 Sayı:3, 57-66.

Dilbirliği, E. (2007). Biyolojik çeşitlilik ve genetik kaynakların sürdürülebilir kullanım stratejilerinin değerlendirilmesi üzerine bir araştırma. Ankara: Ankara Üniversitesi Fen Bilimleri Enstitüsü Peyzaj Mimarlığı Anabilim Dalı Doktora Tezi.

Doğan, S., Türk, M. B., Doğan, S., \& Kesik, O. A. (2018). Biyoçeşitliliğ̆in izlenmesi ve korunmasında coğrafi bilgi sistemlerinin (CBS) kullanımı. International Eurasian Conference on Biological and Chemical Sciences (EurasianBioChem 2018), April 26-27 (s. 284-288). Ankara. Retrieved from www.eurasianbiochem.org.

EEA. (2015). The European environment - state and outlook 2015: (SOER). Copenhagen: European Environment Agency (EEA) EU Bookshop (http://bookshop.europa.eu). FAO. (2019). Türkiye' nin biyoçeşitliliği: genetik kaynakların sürdürülebilir tarım ve gıda sistemlerine katkıs1. Ankara: 222 s. Licence: CC BY-NC-SA 3.0 IGO.

Food \& Biodiversity (2020). Easy Guide - part of the EU LIFE Project: Biodiversity in Standards and Labels for the Food Industry. Business-Biodiversity. Retrieved from https://www.business-biodiversity.eu/en/biodiversity 19.11.2020 .

Gürbüz, H., Derman, M., \& Çakmak, M. (2013). Biodiversity literacy scale: development, validity and reliability. Electronic Journal of Education Sciences Vol: 2 Issue: 3, 7791.

Keleş, F., \& Özenoğlu, H. (2017). Ortaokul öğrencileri için biyolojik çeşitlilik konusunda ders planı tasarlama. Journal of Educational Sciences Adnan Menderes Üniversitesi Eğitim Fakültesi Eğitim Bilimleri Dergisi, Aralık 2017, 8(2), 41-65.

Kurumlu, M. S., Atik, A. D., \& Erkoç, F. (2010). Biyoçeşitliliğin önemi ve koruma stratejileri üzerine biyoloji öğretmenlerinin yeterliklerinin araştırılması. Biyoloji Bilimleri Araştırma Dergisi (BIBAD) 3 (2): 75-82, 2010 ISSN: 1308-3961 
MEB. (2018). Ortaöğretim Coğrafya Dersi Öğretim Programı. Milli Eğitim Bakanlığı, Talim Terbiye Kurulu Başkanlığı. MEB Talim Terbiye Kurulu Başkanlığı. adresinden alınmıştır

MEB. (2018b). Fen Bilimleri Dersi Öğretim Programı (İlkokul ve Ortaokul 3, 4, 5, 6, 7 ve 8. Sınıflar). Ankara: Milli Eğitim Bakanlığı, Talim Terbiye Kurulu Başkanlığı.

Merriam, S. B. (1998). Case Study Research in Education A Qualitative Approach. San Francisco: Jossey-Bass Publishing.

MFA. (2020). Biyolojik Çeşitlilik, Birleşmiş Milletler Çevre ve Kalkınma Konferansı: Rio Bildirgesi (1992). T.C. Dışişleri Bakanlığı: http://www.mfa.gov.tr/biyolojikcesitlilik.tr.mfa 30.11.2020 took in from address.

Naumann, S., \& Davis, M. (2020). Biodiversity and Nature-based Solutions. Analysis of EU- Commission funded projects ISBN 978-92-76-18204-7, doi:10.2777/183298 Luxembourg: Publications Office of the European Union.

nuhungemisi.gov.tr. (2019). Türkiye'nin Biyolojik Çeşitliliği. Ankara: T. C. Tarım ve Orman Bakanlığı, Doğa Koruma ve Milli Parklar Genel Müdürlüğü, Nuh'un Gemisi Ulusal Biyolojik Çeşitlilik Veritabanı, Retrieved from http://www.nuhungemisi.gov.tr/.

RG. (1996). Biyolojik çeşitlilik sözleşmesi. Resmi Gazete (Tarih:27.12.1996, Sayı: 22860). Retrieved from https://www.resmigazete.gov.tr/arsiv/22860.pdf

Stahl, K., Lepczyk, C. A., \& Christoffel, R. A. (2020). Evaluating conservation biology texts for bias in biodiversity representation. PLoS ONE 15 (7): e0234877. Retrieved from https://doi.org/10.1371/journal.pone.0234877, v1-11.

TUBÇSEP (2007). Türkiye Ulusal Biyolojik Çeşitlilik Stratejisi ve Eylem Planı. Ankara: T.C. Çevre ve Orman Bakanlığı, Doğa Koruma ve Milli Parklar Genel Müdürlüğü, Doğa Koruma Dairesi Başkanlığı, Biyolojik Çeşitlilik Sözleşmesi Ulusal Odak Noktasi.

TYVT (2020). Coğrafya Lisans Diploması Yeterliliği. Türkiye Yeterlilikler Veri Tabanı: Retrieved in 30.11.2020 from https:/tyc.gov.tr/yeterlilik/cografya-lisansdiplomasi-TR00310359.html

UNDP.org. (2020). Sürdürülebilir Kalkınma Amaçları. Birleşmiş Milletler Sürdürülebilir Kalkınma Türkiye. Retrieved in 28.11.2020 from https://www.tr.undp.org/content/turkey/tr/home/sustainable-developmentgoals.html

Yıldırım, A., \& Şimşek, H. (2013). Sosyal Bilimlerde Nitel Araştırma Yöntemleri. Ankara: Seçkin Yayınclık Dokuzuncu Baskı. 
Author(s) will retain the copyright of their published articles agreeing that a Creative Commons Attribution 4.0 International License (CC BY 4.0) terms will be applied to their work. Under the terms of this license, no permission is required from the author(s) or publisher for members of the community to copy, distribute, transmit or adapt the article content, providing a proper, prominent and unambiguous attribution to the authors in a manner that makes clear that the materials are being reused under permission of a Creative Commons License. Views, opinions and conclusions expressed in this research article are views, opinions and conclusions of the author(s). Open Access Publishing Group and European Journal of Education Studies shall not be responsible or answerable for any loss, damage or liability caused in relation to/arising out of conflicts of interest, copyright violations and inappropriate or inaccurate use of any kind content related or integrated into the research work. All the published works are meeting the Open Access Publishing requirements and can be freely accessed, shared, modified, distributed and used in educational, commercial and non-commercial purposes under a Creative Commons Attribution 4.0 International License (CC BY 4.0). 